\title{
UTÁNGYÁRTOTT FOGASKEREKEK MEGHIBÁSODÁSA
}

\section{MALFUNCTION OF REMANUFACTERED GEARS}

\author{
Csorba Béla ${ }^{1}$, Végvári Ferenc ${ }^{2}$ \\ ${ }^{1,2}$ Neumann János Egyetem,GAMF Müszaki és Informatikai Kar, Magyarország, \\ Kecskemét, Izsáki út 10 Tel: +36-20/371-41-64 \\ ${ }^{1}$ Természet- és Müszaki Alaptudományi Tanszék, csorba.bela@gamf.uni- \\ neumann.hu, \\ ²Anyagtechnológiai Tanszék, vegvari.ferenc@gamf.kefo.hu
}

\begin{abstract}
Gears are required for piece producted or gearboxes to be refurbished. Adequate consideration must be given to the material selection and heat treatment of these gears. Inappropriate material selection or heat treatment will lead to premature failure of the manufactured gears or early refurbishment. In our publication, we present a number of practical failures that can be traced back to the wrong material selection or heat treatment operation.
\end{abstract}

Keywords: material selection for gears, heat treatment for gears, gears failure.

\section{Összefoglalás}

Egyedi gyártású hajtómüvekben, illetve felújítandó hajtómüvekben szükség van fogaskerekekre. Ezen fogaskerekek anyagmegválasztására és hőkezelésére kellő figyelmet kell fordítani. A nem megfelelő anyagmegválasztás, vagy a helytelen hőkezelés a gyártott fogaskerekek idő előtti ismételt meghibásodásához, illetve a korai újbóli felújítás igényéhez vezetnek. Publikációnkban olyan a gyakorlatban elöforduló hajtómü meghibásodásokat mutatunk be, amelyek visszavezethetök a helytelen anyagmegválasztásra, illetve a nem megfelelö hökezelési müveletre.

Kulcsszavak: fogaskerekek anyagmegválasztása, fogaskerekek hökezelése, fogaskerekek meghibásodása.

\section{Fogaskerekek tönkremenetele}

Müszaki életben szükség van gyakran egyedi fogaskerekes hajtómüvek tervezésére, kivitelezésére, illetve az évek óta használt, kopott fogaskerekes hajtómüvek felújítására. Ha a gyártás és a felújítás nem tükrözi a kellő szakértelmet, az a legyártott hajtómüvek idő előtti meghibásodásához vezet.

\section{Anyagmegválasztás}

A gyártási müvelet első lépése a kiinduló anyag megválasztása. Az anyagmegválasztásnál figyelembe kell venni a gyártandó fogaskerék méreteit, a modul nagyságát, az igénybevétel módját, illetve a gyártandó darabszámot is. Míg egy kevésbé igénybevett fogaskeréknek megfelelhet egy ötvözetlen acél is, az igénybevétel növekedésével szükségessé válik a króm-, mangánötvözésű acélok közül választani. Erős dina- 
mikus igénybevételnek kitett fogaskerekek esetén az előző ötvözőkön túl még szükség lehet nikkellel is ötvözött acélt választani. $\mathrm{Az}$ alábbiakban bemutatunk olyan meghibásodásokat, amelyek helytelen anyagmegválasztásból eredtek.

\section{1. Ötvözetlen szerkezeti acél válasz- tása}

Egyik nagyon súlyos hiba, ha a kiinduló alapanyagnak ötvözetlen szerkezeti acélt választanak. Régi jelölésekkel A50, A60, újabb jelöléssel S355J2. Ez az acél nem tartozik a hőkezelhető acélok közé. Az így gyártott fogaskerék legfeljebb geometriára lehet helyes, de igénybevételre, általában nem felel meg. Egy általános rendeltetésủ szerkezeti acélból készített, idő előtt tönkrement kúpfogaskerék látható az 1. ábrán. A fogak rövid használat után erősen koptak, kihegyesedtek.

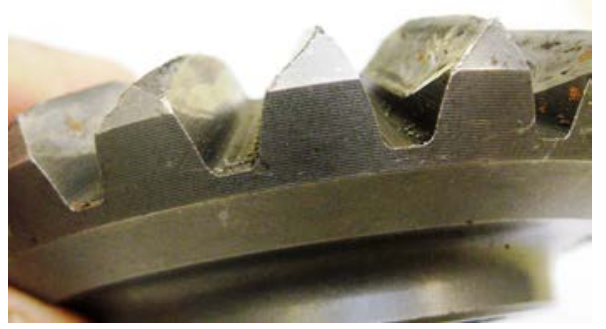

1. ábra. Szerkezeti acélból készült gyorsan kopott fogaskerék

Jobb minőségü, hőkezelhető acélok alkalmazásánál is jelentkezhetnek problémák, ha a hökezelést elhagyják, vagy helytelenül hajtják végre. A 2. ábrán egy $132 \mathrm{kW-os,}$ Flender KENW 320 szivattyú hajtómüvének meghibásodott fogaskerekét mutatjuk be, ahol az üzemidő mindössze 159 óra volt [1]. A 2. ábrán látható fogaskerék C60 anyagminőségből készült. A kéregvastagság keresése miatt a fogfelületre merölegesen keménységmérést végeztünk, amely eredményeit a 3. ábrán mutatjuk be. Az ábra szerint látható, hogy a felületen kéreg nem volt. A mért 300HV1 keménység egy nor- malizált, esetleg egy nagyon visszaeresztett szövetszerkezetet jelenthetne.

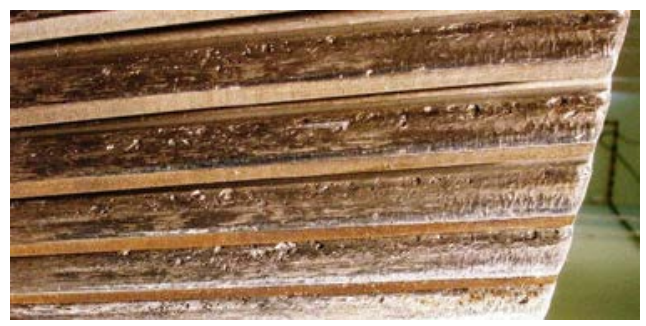

2. ábra. C60 acélból készült hökezeletlen fogaskerék 159 óra üzemidő után

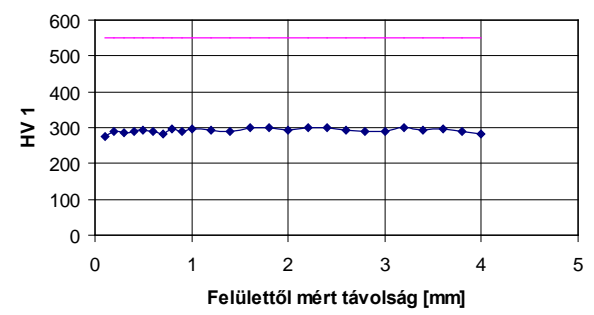

3. ábra. Látható, hogy a C60 acélból készült fogaskeréken nincs keményített kéreg

\section{2. Ötvözött szerkezeti acél választá- sa}

A fogaskerekek készülhetnek ötvözött nemesíthető acélból is. A 4. ábrán az előző hajtómüből származó nagyobb igénybevételnek kitett 42CrMo4 acélból készült ferdefogazatú fogaskerék tönkremenetelét mutatjuk, amely a 159 óra üzemidő alatt következett be.

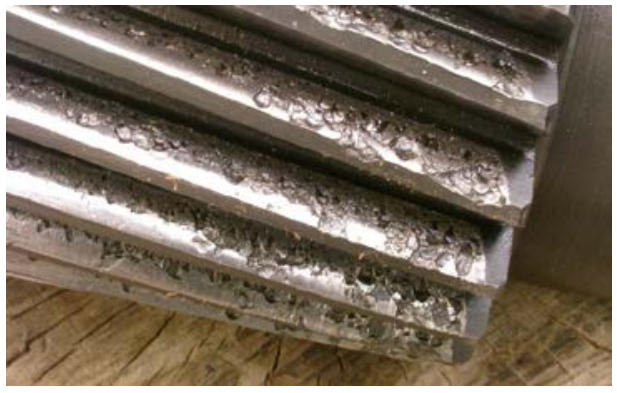

4. ábra. 42CrMo4 acélból készült hökezeletlen fogaskerék tönkremenetele 159 óra üzemidő alatt 
A fogaskeréken kéregvastagság itt sem volt felfedezhető. A keménység ennél is $300 \mathrm{HV} 1$ volt. A fogak felületén nagymértékü kipattogzás található, amely a nagy fellépő feszültség (Hertz-feszültség) következtében bekövetkezett felületi kifáradás következménye. Ezt jól bizonyítják a felületre merőleges metszeten látható, kifáradásból bekövetkezett repedések is (5. ábra).

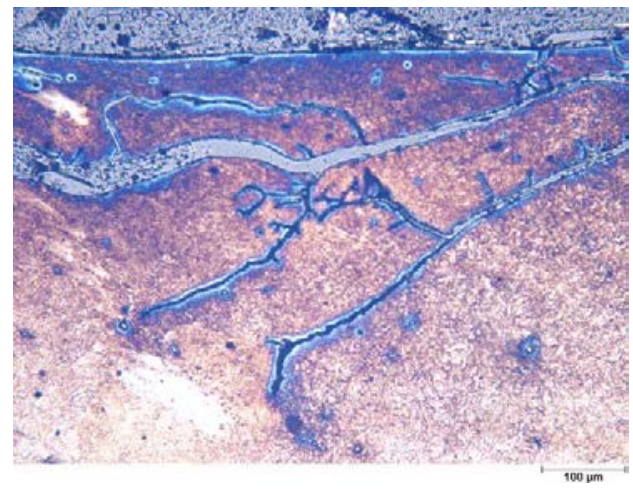

5. ábra. Felületi kifáradásból keletkezö repedések

\section{Hőkezelés}

A helyes anyagmegválasztás után a legyártott fogaskerekeket hőkezelni is kell. A müveletet megfelelő gondossággal és körültekintéssel kell elvégezni.

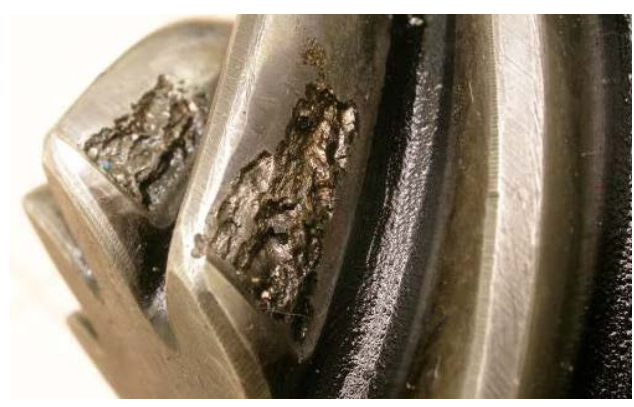

6. ábra. $16 M n C r 5$ acélból készült betétedzett nyeleskerék tönkremenetele egy hét üzemidö alatt

A 6. ábrán egy betétben edzhető 16MnCr5 anyagból készült, betétedzett nyeleskerék tönkre menetele látható. Az alkatrész folyamatosan müködve nem érte el meghibásodás nélkül az egy hetet. A betétedzés során elért kéregvastagságot meghatároztuk (7. ábra), amely méréseink szerint 0,85 mm-re adódott.

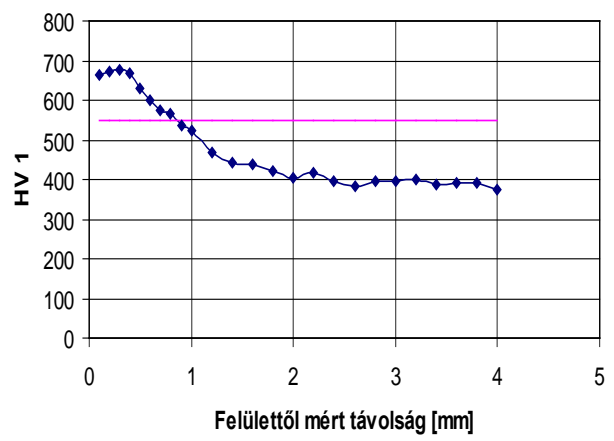

7. ábra. $16 M n C r 5$ acélból készült betétedzett nyeleskerék kéregvastagsága

A fenti nyeleskerék nagy felületi nyomásnak volt kitéve, a felületen ébredő feszültség valószínü, hogy meghaladta a Hertz feszültségre megengedett értékét, így az ismétlődő igénybevétel miatt erősen kigödrösödött. A fogaskeréken lévő kéregvastagság az 5 - 6 modulra javasolt kéregvastagság alsó határán van (0,8 - 1,2 mm). A nagyobb felületi feszültség létrejöttében szerepet játszott az is, hogy pontatlan gyártás, vagy szerelés következtében a fogak nem terhelödtek egyenletesen a teljes hoszszuk mentén. A nyomaték átvitele csak a fogak hosszának felére terhelődött.

\section{Felújítás}

A mezőgazdasági gépek sok esetben igen mostoha körülmények között üzemelnek. A fogaskerék hajtások sok esetben ki vannak téve az időjárás körülményeinek, csapadéknak, pornak stb. Kenés hiányában a kopás gyorsan jelentkezik (8. ábra). Sokszor a védettebb helyen lévő fogaskerekek is jelentősen poros környezetben üzemelnek. 


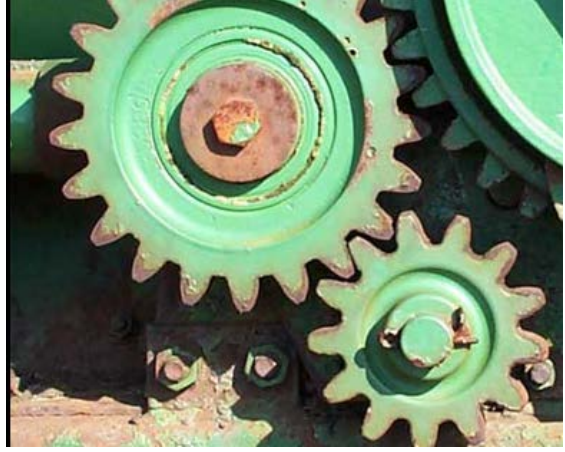

8. ábra. Mezögazdasági gép szabadban üzemelö fogaskerekei [3]

A mezőgazdasági gépek fogaskerekeinek felújítása is hiányolja esetenként a szakértelmet, vagy a felelősséget. A 9. ábrán bemutatott bordás tengely bordái pár órás üzemidő után kihegyesedtek. Az alkatrészről készült csiszolatból kiderült, hogy a meghibásodott bordázat javítása hegesztéssel történt (10. ábra). A felhegesztett rész keménysége csak 220 - 230HV0,2.

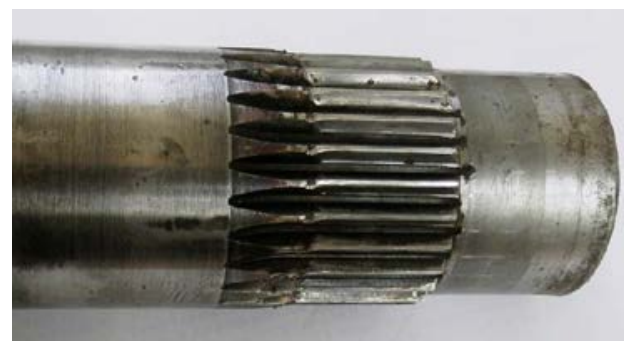

9. ábra. Mezögazdasági gép felújitás után kihegyesedett fogazott tengelye

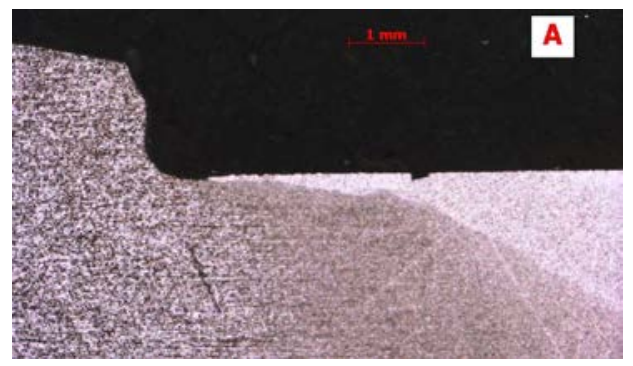

10. ábra. A fogazott tengely javítása hegesztéssel történt

\section{Következtetések}

a) A kis sorozatba, vagy felújításra gyártandó fogaskerekek anyagának betétben edzhető vagy nemesíthető acélt kell választani.

b) A jól megválasztott anyagminőség esetén is hökezeléssel kell kellö vastagságú cementált vagy kéregedzett kérget biztosítani.

c) Fogaskerekek felújításánál a hőbevitel kilágyulással jár.

\section{Köszönetnyilvánítás}

Köszönettel tartozunk a kutatás támogatásáért, amely azEFOP-3.6.1-16-201600006 „A kutatási potenciál fejlesztése és bővítése a Neumann János Egyetemen" pályázat keretében valósult meg. A projekt a Magyar Állam és az Európai Unió támogatásával, az Európai Szociális Alap társfinanszírozásával, a Széchenyi 2020 program keretében valósul meg.

\section{Acknowledgement}

This research is supported by EFOP3.6.1-16-2016-00006 "The development and enhancement of the research potential at John von Neumann University" project. The Project is supported by the Hungarian Government and co-financed by the European Social Fund.

\section{Szakirodalomi hivatkozások}

[1] Bernáth, M.; Végvári, F: Flender KENW 320 szivattyú hajtómüvének meghibásodása. MECH-TECH Hőkezelő Bt Szakvélemény 2011.

[2] Bernáth, M.; Végvári, F: Kukorica betakarító kombájn csötörö adapter tönkremenetelének vizsgálata, MECH-TECH Hökezelő Bt Szakvélemény 2014.

[3] https://hu.wikipedia.org/wiki/Fogasker\%C3\%A9k 